\title{
Science outside the classroom: Exploring opportunities from interdisciplinarity and research-practice partnerships
}

\author{
Gonzalo R. Guerrero ${ }^{1,2}$, Michael J. Reiss ${ }^{1}$ \\ ${ }^{1}$ UCL Institute of Education, London, UK; ${ }^{2}$ Universidad de Santiago de Chile, \\ Santiago, Chile
}

Gonzalo R. Guerrero-Hernández: PhD student in Curriculum, Pedagogy and Assessment, Institute of Education, University College London, UK. Physics and Maths' Teacher and Researcher in Didactics of Experimental Sciences, Universidad de Santiago de Chile.

Michael J. Reiss: Professor of Science Education in Curriculum, Pedagogy and Assessment, Institute of Education, University College London, UK and a Fellow of the Academy of Social Sciences. The former Director of Education at the Royal Society, he has written extensively about curricula, pedagogy and assessment in science education. 


\title{
Science outside the classroom: Exploring opportunities from interdisciplinarity and research-practice partnerships
}

\begin{abstract}
This article examines an outdoor science activity based on Interdisciplinary Teaching and Learning of Science (ITLS) undertaken with a collaborative research methodology as a Research-Practice Partnership (RPP). The ITLS activity was implemented in the Río Clarillo National Reserve in Chile as part of a continuing professional development unit. It was co-designed by in-service science teachers on a Chilean Master's degree programme and researchers. The study aimed at answering the following research questions: 1) How do in-service teachers, working in a RPP, connect and articulate different science topics through methodological and theoretical interdisciplinary perspectives? 2) Can a RPP be a pedagogical resource to generate positive changes in professional development within the practice of managing outdoor science activities? This analysis was qualitative and based on content analysis of data collected from (a) questionnaires about the teachers' perceptions and (b) scientific posters designed by the teachers as part of the final assessment of their course. The main findings revealed that teachers were able to connect interdisciplinary topics - using theoretical and methodological interdisciplinarity - to solve real problems that arise from the environment within a field trip. In addition, findings reveal benefits of RPP and ITLS, as a tool for the management of outdoors activities, supporting the importance and relevance of learning of science outside the classroom. However, the boundaries between researchers and science teachers should consider the cultural worlds of participants in the partnerships.
\end{abstract}

Keywords: Outdoor science teaching, Professional Development, Interdisciplinarity, Collaborative learning 


\section{Introduction}

In recent years, growing attention has been paid to out-of-school science teaching settings and its impact on students' learning. Outdoor science activities positively influence attitudinal, physical/behavioural and inter-social constructs among students (Rickinson et al., 2004). In particular, researchers, teachers and policy-makers have highlighted the crucial role of the learning of science outside the classroom regarding the promotion of more connections with complex and real-life (Behrendt \& Franklin, 2014; King \& Glackin, 2010). In this context, where science education lacks authenticity - because many concepts are taught in an abstract way - it has been claimed that more connection with real life contexts should be established to counterbalance this situation (Bencze \& Hodson, 1999).

From this perspective, teachers need to enact the teaching of science drawing on a wide range of ideas and experiences (Glackin \& King, 2018). In particular, activities based on environments outside the classroom offer real-world opportunities to observe scientific concepts which are located within special contexts that address and traverse traditional boundaries between biology, chemistry, geology and physics (Glackin \& King, 2018; Glackin, King, Cook, \& Greer, 2018).

Nevertheless, some studies highlight a significant challenge related to outdoor science learning, namely that most science teachers have limited pedagogical expertise in terms of planning and preparing activities outside the classroom (Ayotte-Beaudet, Potvin, Lapierre, \& Glackin, 2017). Relatedly, K-12 science teachers infrequently incorporate outdoor learning into their practices (Power, Taylor, Rees, \& Jones, 2009). For that reason, teachers need to be supported in their initial and continuing professional development, to cultivate dispositions and skills so that they feel confident to work with activities outside the classroom (Glackin et al., 2018).

Within this scenario, interdisciplinarity and interdisciplinary teaching and learning of science (ITLS) has appeared as a pedagogical resource to promote the learning of science outside the classroom (Klein, 2005), particularly as a way to: i) encourage K-12 science teachers in their development and planning of outdoor activities, integrating propositions and concepts across disciplines (theoretical interdisciplinarity) and borrowing methods from other disciplines (methodological interdisciplinarity) (Miller, 1982); and, ii) as a resource to lead students to the understanding of their own environment and/or, at the same time, of the global environment (Boix Mansilla, 2017). Thus, students might become aware of their 'glocal' (global and local) environment, to develop the ability to relate local problems to global scenarios (Murga-Menoyo \& Novo, 2017).

This study proposes a methodology based on Research-Practice Partnerships (RPPs) (Penuel, Allen, Coburn, \& Farrell, 2015) as a potential pedagogical and collaborative tool to support and generate positive changes in the process of management of outdoor science teaching, and, at the same time, to fulfil the potential of interdisciplinarity as a resource to strengthen learning and teaching outside the classroom.

This research therefore examines an ITLS activity outside the classroom conducted in the Río Clarillo National Reserve, in the central zone of Chile. The outdoor activity was carried out through three interdisciplinary projects developed from a RPP framework and co-designed with in-service science teachers on Chilean Master's degree programme, supported by researchers. The study aimed at answering the following research questions: 1) How do in-service teachers, working in an RPP, connect and articulate different science topics through methodological and theoretical interdisciplinarity perspectives? 2) Can an RPP be a potential pedagogical resource to 
generate positive changes in professional development within the practice of managing outdoor science activities? The findings are presented and analysed from the following perspectives: a) interdisciplinary science topics, methods and content selected by inservice science teachers in each project (use of methodological and theoretical interdisciplinarity); b) teachers' perceptions of ITLS through outdoor science activities and collaborative research grounded in RPPs; and c) ITLS and RPPs as tools for the improvement of the management of outdoor science activities by science teachers.

\section{Teaching and learning of science outside the classroom}

Science outside the classroom is usually envisaged as trips or pedagogical itineraries that are designed for an educational purpose in which students interact with the environment or exhibitions (e.g. local nature reserves, zoos, botanic gardens, museums, farms, streetscapes, and so on) (Rennie, 2014). These activities provide pedagogical opportunities to develop experiential connections and knowledge of an object, idea, concept, theme or operation (Falk \& Dierking, 1997; Krepel \& Duvall, 1981; Nabors, Edwards, \& Murray, 2009; Scarce, 1997).

In terms of students' learning, science education in contexts other than the classroom can show significant benefits (King \& Glackin, 2010). In particular, activities carried out outside the classroom complement pedagogical resources to help students in multiples domains of learning - cognitive, affective, physical and behavioural (Mohamed, Perez, \& Montero, 2017). It is through contact with reality that students can be helped to relate theory to the practical value of the learning they are building, which can generate meaning and a positive attitude towards the topics addressed in the outdoor activities (Behrendt \& Franklin, 2014). Such learning motivates students to develop connections between theoretical concepts seen in classes and what they experience empirically (Falk, Martin, \& Balling, 1978; Hudak, 2003). Moreover, learning beyond the classroom has been shown to have the capacity to link knowledge to most areas of curriculum and can be a positive influence on students' understanding, interest and motivation (Braund \& Reiss, 2006).

With regards to the nature of outdoor science activities, some studies indicate that in order to reach optimal levels of learning, outdoor science activities must be carefully planned (Dillon et al., 2005). These findings imply that outdoor science activities must be related to activities developed in the classroom in order to favour inquisitive behaviour involving conceptual and attitudinal learning and development of skills in science (Falk \& Dierking, 2000).

Nevertheless, although several studies indicate that students increase their knowledge as a result of outdoor activities, teachers typically have difficulties developing outdoor initiatives related to its implementation in the classroom (AyotteBeaudet et al., 2017). Furthermore, most science teachers have limited pedagogic knowledge and teacher training regarding the process of planning and preparing such activities (Michie, 1998; Tal \& Morag, 2009). In addition, a series of obstacles exists in utilising this pedagogic tool, including: the large number of logistical (including bureaucratic) challenges to which teachers are currently subjected by educational institutions; the pressures to fulfil the curriculum of the subject; the financial costs of trips; the connotation of outdoor science as leisure-time and consequently a loss of time for teaching; the increase in the number of extra-academic activities in which students participate; the concern about health and safety issues; and the problems with scarcities of time, resources or support (Marchant et al., 2019; Mohamed et al., 2017; Rickinson et al., 2004). 


\section{Theoretical and methodological approach to interdisciplinarity}

The synthesis, integration or blending of knowledge has been understood as the defining characteristic of interdisciplinarity. However, the definition of interdisciplinarity and a set of terms to delineate interactions of disciplines into classifications of multi-, pluri-, inter-, and trans-disciplinarity is complex. The initial use of interdisciplinarity emerged during the 1970s, created for an international conference co-sponsored by the Organization for Economic Cooperation and Development (OECD) (Klein, 2017). The OECD's definition of interdisciplinarity was broad, including any kinds of interaction defined as "simple communication of ideas to the mutual integration of organizing concepts, methodology, procedures, epistemology, terminology, data, and organization of research and education" (Apostel, Berger, Briggs, \& Michaud, 1972, p. 25). According to this definition, interdisciplinarity tends to be conceptualized epistemologically, in terms of using a simple 'blend', 'integration' or 'combination' of different types of disciplinary knowledge (Frodeman, 2014).

Nevertheless, 'simple communication' does not involve key attributes of interdisciplinarity (Knight, Lattuca, Kimball, \& Reason, 2013; Lattuca, 2001). For that reason, we favour the definition of interdisciplinarity provided by (Boix Mansilla, Gardner, \& Miller, 2000, p. 219):

The capacity to integrate knowledge and modes of thinking in two or more disciplines or established areas of expertise to produce a cognitive advancement such as explaining a phenomenon, solving a problem, or creating a product - in ways that would have been impossible or unlikely through single disciplinary means.

This definition builds on a performance-based view of understanding, meaning that individuals understand a concept when they are able to apply it - or think with it accurately and flexibly in novel situations (Boix Mansilla et al., 2000).

Differences are further evident in the distinction between methodological and theoretical interdisciplinarity, and there are both narrow and broad definitions of interdisciplinarity, depending on the number of disciplines involved and the compatibility of their epistemological paradigms and methodologies (Klein, 2017). Theoretical interdisciplinarity "implies an epistemological form embodied in creating conceptual frameworks for analysing particular problems, integrating propositions and concepts, connecting topics across disciplines, and synthesizing continuities between models and analogies" (Klein, 2017, p. 7). On the other hand, methodological interdisciplinarity "promote[s] the improvement of the quality of results, typically by borrowing a method from another discipline to test a hypothesis, to answer a research question, or to help develop a theory" (Bruun, Hukkinen, Huutoniemi, \& Klein, 2005)

In the area of science education, previous studies have reported an explosion in the number of educational programmes which intend to promote and integrate theoretical and methodological interdisciplinarity across a wide variety of curriculum proposals (Tobi \& Kampen, 2017), and there is a growing recognition of the importance of teaching and learning science through an interdisciplinary approach (You, 2017). For instance, the Next Generation Science Standards (NGSS) highlight that students need to integrate modes of thinking and knowledge informed by a variety of science and engineering disciplines - e.g. STEM (Science, Technology, Engineering and Mathematics), STEAM (Science, Technology, Engineering, Arts and Mathematics) and others (NGSS lead NGSS, 2013states). In addition, a potential answer to the relatively low levels of understanding and poor attitudes towards STEM is the introduction of 
interdisciplinary teaching which emphasizes how knowledge from more than one discipline contributes to an understanding of the natural world (Madden et al., 2013). Moreover, various international standards have already proposed the need for interdisciplinary learning for the development of scientific knowledge (OECD, 2018).

There is today a greater enthusiasm for ITLS due to a growing recognition that many of today's global scientific challenges - such as climate change, pollution, use of energy, among many others - involve interactions between humans and their environment. A monodisciplinary approach is unable to capture the complexity of these challenges (Gehlert et al., 2010). Consequently, the involvement of scientists and citizens with different disciplinary backgrounds (social sciences, environmental sciences, climatology, health sciences, engineering, etc.) is required (Boix Mansilla \& Duraisingh, 2007; DeZure, 2017; Klein, 2017; You, 2017).

The ability to draw on both theoretical and methodological interdisciplinarity is considered as a favourable learning outcome of interdisciplinary education (Spelt, Biemans, Tobi, Luning, \& Mulder, 2009). Studying the complexity of a natural system it is not easy, and to succeed necessitates interdisciplinary understanding informed by the integration of different disciplinary backgrounds (You, 2017). ITLS can provide an integration of knowledge, theories and methods from the different subjects that influence the construction of learning among students in outdoor science activities (Guerrero et al., 2019). Considering these discussions in the literature, the theoretical framework of this research drew on both theoretical and methodological interdisciplinarity.

\section{ITLS in the Chilean context}

Even though there has been a considerable increase in the adoption of explicit interdisciplinary goals for teaching, learning and assessment methods through an interdisciplinary approach (DeZure, 2017), there remain fundamental questions among teachers about what constitutes interdisciplinarity and which teaching methods can be used to design and assess such activities. Thus, notwithstanding the observation that interest in interdisciplinary teaching and learning is high, institutions continue to struggle with how to design, teach and assess so as to fulfil the potential of interdisciplinarity (DeZure, 2017).

In Chile, the government proposed, in 2019, a curriculum reform, promoting an integration of school science with other disciplines through the approach of STEM education. Although the educational pendulum is moving in Chile in a direction that is more favourable to interdisciplinary education, science lessons today focus on learning in monodisciplinary configurations, which impacts on students and results in restricted and disjointed knowledge. Chilean science education is disjointed from the real and complex world and fails to meet the needs and interests of students (Perales \& Guerrero, 2017). According to the National Commission for Scientific and Technological Research of Chile (CONICYT in Spanish), this situation has led in recent years to a steady decline in the number of students who are choosing scientific careers.

At the same time, there has been a decrease in the annual recruitment rate of physics, chemistry and biology teachers in Chile, which is now $2.3 \%, 6.1 \%$ and $6.1 \%$ respectively (CIAE, 2018). A recruitment rate of less than about $4 \%$ in any subject indicates that a sufficient number of teachers is not being trained to meet the demand for teachers (CIAE, 2018). In this regard, the physics situation is worrying. 


\section{Science outdoors as an opportunity to apply interdisciplinarity}

Taking into account the literature reviewed above, an ITLS approach to the learning of science outside the classroom appears as a good platform to improve the management of activities outside the school. An ITLS approach also seems to provide an opportunity to address contemporary environmental problems by applying theoretical and methodological interdisciplinarity from multiple perspectives and ways of thinking (Klein, 2017; You, 2017). Given this, and the fact that it has been argued that there is a need for further studies on the most effective ways to teach science outside the classroom (Ayotte-Beaudet et al., 2017), this study takes from previous evidence a number of ways in which out-of-classroom contexts can provide an opportunity to apply interdisciplinarity to improve the learning of science:

(1) This kind of approach might develop, integrate and tackle concepts, addressing the excessive fragmentation of the school science curriculum (Nabors et al., 2009).

(2) This approach offers the opportunity for students to give their own meanings to interactive activities during field trips, connecting different areas of knowledge (Mohamed et al., 2017; Power et al., 2009; Spelt et al., 2009), generating a change in the way in which understanding is developed and scientific skills are practised.

(3) Outdoor science activities might generate extended and authentic practical work and access to 'big' science and to 'real data'(Glackin, 2019).

(4) Outdoor science activities might promote positive attitudes to school science, stimulating further learning and such social outcomes as collaborative work and responsibility for learning (Braund \& Reiss, 2006).

\section{Methods}

This research adopted a qualitative approach while investigating interdisciplinary science projects that were undertaken outside the classroom and involved a total of nine in-service science teachers and three science education researchers working in three Research-Practice Partnership (RPPs). The study was implemented in the Río Clarillo National Reserve, which preserves native species and their natural environment, being the closest national park to Santiago, the capital of Chile. Nine teachers were enrolled on a Science Education Master's degree programme for which developing an outdoor science activity in one of physics, earth sciences, chemistry or biology was the final assignment. The MA programme considered all these science disciplines since science teachers had different backgrounds. Therefore, the activity was planned as the final assignment of the first term and one that was also a potential activity to be implemented by science teacher with school learners. Qualitative data from interviews with the teachers, field observations of teachers' management and organisation during the outdoor science activity, and materials generated as a result of the interdisciplinary projects were analysed using the Software NVIVO 12.

For ethical reasons, the study did not use the real names of the participants. Instead, an encoding process was employed with code names in the transcripts. Informed consent was obtained according to the research ethics committee requirements of the university in Chile at which the first author was based while the study was undertaken, and data collected. 


\section{Research-Practice Partnerships (RPPs) and interdisciplinary projects}

In this study, we propose a methodology based on the conceptual framework of Research-Practice Partnerships (RPPs) (Penuel et al., 2015) as a pedagogical resource for bringing about positive outcomes in the process of managing outdoor science teaching and achieving the potential of interdisciplinarity as a resource to strengthen learning outside the classroom.

RPPs are collaborative partnerships between researchers and practitioners contributing to more robust educational theory and practice (Penuel et al., 2015). A RPP can enhance the role of teacher as researcher on in-service teachers' professional development. In this case, we developed RPPs as a resource to manage and support interdisciplinary science learning outside the classroom.

The activity carried out through RPPs resulted in three different interdisciplinary projects where in-service teachers identified problems and proposed common work objectives, addressing conceptual, procedural and attitudinal aspects in an interdisciplinary curricular way, using their own experience of learning and science content seen during classes. Table 1 summarises the science projects undertaken by the teachers and the teacher and researcher profiles.

[Table 1 near here]

\section{Research-Practice Partnerships}

In undertaking this study, the outdoor science activities were organised between inservice teachers on a Master's degree programme in Chile and university researchers, all of whom were science educators. The teachers participated in all phases of the outdoor science activity, including derivation of the problem statement, data collection, data analysis, planning, evaluation and execution. The process and phases of preplanning, execution and post-pedagogical activities are illustrated in Figure 1.

[Figure 1 near here]

\section{Planning a field trip}

Based on the literature, researchers and teachers defined the typology of pedagogical activities outside the classroom. This design is part of a sequence of steps to plan a pedagogical field trip as suggested by Delgado and Alario (1994), who saw the potential for such a field trip to be an activity that is carried out outside the school in order to cover some of the objectives of the curriculum. According to the thematic content of the activity, the out-of-school experience was understood by the participants as an interdisciplinary pluri-thematic activity which addresses the observation and analysis of reality as a whole, with the purpose of obtaining sufficient data to interpret it.

Methodologically speaking, and given the nature of the activity, the typology of the field trip was based on a mixed design (Delgado \& Alario, 1994). On the one hand, the experience was developed by a guided activities session. Teachers tackled questions developed by researchers about aspects of the itinerary which were considered to be of special educational merit. As Falk et al. (1978) pointed out, excessive novelty can distract learners. On the other hand, the activity was exploratory and open; although students have prior information, all kinds of information about various topics are collected along the way, revealing the interdisciplinary nature of the activity (Delgado \& Alario, 1994). 


\section{Constituting a research-practice partnership}

According to the profiles of each of the teachers, heterogeneous groups of three teachers were incorporated into each RPP. The criteria were such that the groups consisted of teachers with different disciplines and, if possible, were as diverse as possible (see Appendix 1 for teachers' profile information). Each of the three researchers provided support across each project. The role of the researchers during the project was to inform, help and co-design strategies for improvement of the outdoor science activities proposed by the teachers. For instance, in the first phase of the RPPs, researchers supported teachers by introducing literature around issues faced by the Río Clarillo National Reserve and around methodological ideas to plan and develop their projects.

\section{Articulating disciplines through interdisciplinarity}

The activity was planned during the sessions of the Master's course. In each module (physics, chemistry and biology) teachers had one hour a week for one month to design the activity. Subsequently, the activity was carried out during a whole day in the month of June (from 0900 until 1700) in the National Reserve Río Clarillo. In the morning there was a meeting between researchers and teachers and during the afternoon the teachers developed the project using the agreed plan. Researchers supported the collection of data and helped answers questions throughout the day.

At the beginning of the activity, the questions were broad: 'What kind of environmental problems do we find in the Río Clarillo National Reserve? How can we solve this real-life problem using collaborative work connecting different disciplines?'. From these questions, the teachers began to investigate in the field, designing the project and formulating their research questions and aims. Teachers collected data during the fieldwork. They also analysed these data, responding to the research questions, aims and hypotheses.

The role of the researchers at this stage was to guide the writing of the research questions and to promote the articulation of the disciplines with the objective of responding to each of the concerns that arose. The idea was to connect some topics introduced during lectures on the Master's course and to find solutions to each of the problems proposed by the teachers. In this way the teachers began to activate the disciplinary, didactic, methodological and pedagogical knowledge of each of the science disciplines. They started working on their problem, selecting samples and finding different methods to be able to respond to the task and each proposed objective.

\section{Doing research and post-field trip activities in the classroom}

After the work in the field, the teachers began to work in the classroom, developing scientific posters, over a total of three sessions, undertaking a deep investigation regarding the problems that arose from the field trip. The work at this stage was autonomous within the groups in the sense that each teacher contributed information from their disciplines and experiences in the fieldwork. The activity with the posters was part of the final assessment on the different courses of the MA programme. Therefore, the aim of the activity included learning about designing scientific posters. The idea was both to provide a formal document to support the research project and also to support activities with their own students in a future pedagogical science outdoor experience. The time provided to develop the posters was about two hours in each module of the MA - in total, approximately six hours. 
In this stage, the researchers provided help in terms of academic guidance for the design of scientific posters and guidelines from the literature to contribute to each project. In addition, teachers received methodological support to organise their projects and a rubric with indicators to prepare the scientific poster.

\section{Data collection}

As part of the data collected, at the end of the activity and as part of the final assessment of the courses (physics, chemistry and biology), teachers had the task of making scientific posters. The posters aimed at teachers developing tools for research and planning an interdisciplinary activity outside the classroom. The posters addressed the research problems, objectives, a theoretical framework, methodology, results and conclusions of the activity. Based on the information from the three scientific posters, a content analysis was conducted to answer the first research question of this paper: 'How do in-service teachers, working in an RPP, connect and articulate different science topics through methodological and theoretical interdisciplinary perspectives?'.

In addition, the teachers completed a questionnaire (see Appendix 2) which was designed to reveal the teachers' perceptions of ITLS through outdoors science activities set in a RPP and to establish their views about RPP and ITLS as tools for improving the management of outdoor science activities. The questionnaire was completed by teachers at the end of the project.

\section{Data analysis}

To analyse the data from the scientific posters we applied thematic and directed analysis of content (Hsieh \& Shannon, 2005) conducted by a more planned process rather than a conventional approach which aims to validate or extend conceptually a theoretical framework or theory (Hickey \& Kipping, 1996; Hsieh \& Shannon, 2005). In the first stage, we started by creating a code bank with predetermined categories and codes of analysis from the literature. This was done both for: (1) Theoretical interdisciplinary codes: (i) integrating propositions and concepts, (ii) connecting topics across disciplines, and (iii) synthesizing continuities between models or analogies from other disciplines (Klein, 2017); (2) Methodological interdisciplinary codes: (i) borrowing a method from another discipline to collect data, (ii) analysing data connecting different methods across disciplines, (iii) testing a hypothesis from different approaches, and (iv) answering the research question or developing a theory (Bruun et al., 2005).

To analyse the data from the questionnaires about teacher perceptions, we used conventional content analysis. In this case, coding nodes were derived directly, allowing the categories and names for categories to flow from the data (Hsieh \& Shannon, 2005). Six themes emerged from the analysis: (1) Perceptions about teaching and learning outside the classroom; (2) Perceptions about ITLS and outdoor science; (3) Teacher management of science activities outside the classroom; (4) Perceptions about RPP and collaborative work; (5) Impact on the researcher-teacher role; and (6) Obstacles and facilitators. We subsequently used these six themes to code the data.

\section{Findings \\ Theoretical and methodological interdisciplinarity within the learning of science outside the classroom}

From the content analysis of the scientific posters designed by the teachers, it was evident that there was a clear interdisciplinary approach. Teachers connected and 
articulated different disciplines, topics, content and methods to improve the quality of each project according to codes presented above. As Table 1 shows, most of the projects integrated disciplinary content, methodologies and topics from chemistry, physics and biology (with a special focus on ecology, plant physiology and botany). Furthermore, two of the groups also connected geography, geology, biochemistry, agrochemistry and agrophysics.

In the case of project 1 , the research question and the study objective draw on theoretical interdisciplinary concepts as is indicated by the title of the project: 'Analysing the incidence and effects of temperature and humidity on the development of the Cestrum parqui species in the Clarillo River National Reserve'. Teachers began by connecting different topics and concepts across disciplines to investigate how temperature and weather affect Cestrum parqui, also known as willow-leaved jessamine - a fast-growing shrub. For instance, a Physics' in-service teacher attributed some connections of the problem to the effect of temperature in the phenomena of capillarity in the plant, linking with Physics and the dynamics of fluids. Also, he connected the effect of the temperature, frosts or frozen dews and relative humidity on changes in the frequency of light to change the green colour and produce a 'new' colour in the damaged leaf. The Biology teacher explained the problem, talking about photosynthesis and leaves' stomata, evapotranspiration and its impact on the absorption of water and nutrients, which may consequently result in the rupture of cell membranes. At the same time, together they were able to connect these topics with an absence of chlorophyll, connecting with Physics again, talking about solar exposure, and length of waves and a phenomenon called 'chlorosis' (insufficient production of chlorophyll by leaves). This information is highlighted in the poster of project 1 . On the other hand, the Chemistry teacher connected the deficit of minerals and the lack of nutrients with the deceleration of chemical reactions, for instance, the production and exchange of $\mathrm{CO}_{2}$ which impacts, again, the weakening of structures such as the cell membrane. This was summarised in his contribution to the initial working hypothesis 'low temperatures and high humidity would directly affect the photosynthetic activity and the chemical composition of Cestrum parqui, preventing its normal development'.

In order to answer the research question, teachers used elements of botany and plant physiology regarding the transpiration of plants (see Figure 2). At the same time, the teachers used elements of geography and climatology to investigate what occurs to the leaves when there is a frost. Also, they were measuring the temperature of the soil and the external environment using methods from physics and chemistry.

[Figure 2 near here]

The results of project 1 show that teachers were able to use theoretical and methodological interdisciplinarity to answer their initial research question. This approach of the teachers is indicated in Figure 3, which is taken from the results section of their scientific poster.

[Figure 3 near here]

From Figure 3, we can appreciate that teachers were able to connect different concepts and disciplines, finding an answer to the problem. In this case, the temperature and humidity affect the species Cestrum parqui in the River Clarillo National Reserve: "These phenomena are producing black spots on the leaves of Cestrum parqui, which is attributed to the cell death which is generated by the alteration of various biological, 
chemical and physical process that occur in the plant." (Findings from scientific poster in project 1)

On analysing project 2, we find both theoretical and methodological interdisciplinarity. For a start, the research question 'How does solar exposure and the behaviour of abiotic factors affect the abundance of flora on the slopes of the Clarillo River National Reserve?' manifests theoretical interdisciplinary, such as "sun exposure, abiotic factors and abundance of flora" (from scientific poster in project 2). Furthermore, the teachers raise different interdisciplinary issues in their theoretical framework:

(1) 'The Río Clarillo National Reserve is located at a latitude of $33^{\circ} 45^{\prime} 48,757^{\prime}$ which establishes the point where it is located on Earth with respect to the equator and estimates the position of the Sun at the time of issuing its solar rays." [Geography]

(2) "The different soils have different proportions of these components, which depend on the conditions of their formation. Soil structure results from longterm interactions of climate, organisms, topography and the mother rock." [Chemistry and geology]

(3) "The basic classification system of native flora (...) determines that the Clarillo River National Reserve is inserted within the ecological region of the scrubland and sclerophyllous forests and the high Andean steppe." [Biology]

The hypothesis integrates elements of theoretical interdisciplinarity by stating that "The solar exposure and radiation [physics] that the hills receive is clearly dissimilar, which determines the characteristic abiotic factors of each hillside [geography and biology], in terms of temperature, humidity, wind speed [physics] and the characteristics of the soil [geology and chemistry]". Similarly to project 1, teachers used methodological interdisciplinary in their data collection, based on basic sampling and analysis methods [from biology, especially plant ecology, physics and chemistry]. In this case, namely from plant ecology and the measurement of humidity and wind speed [physics]. Furthermore, the teachers selected the sampling and experimental method design from a manual on methods of sampling and analysis in vegetable ecology and used a soil science manual to study the influence of soils on living things, particularly plants. Using simple and stratified vegetation sampling [from an agrophysics and agrochemistry approach] they determined the plant abundance in the selected area $(2 \times 2$-meter quadrats). Parts of the poster produced by the teachers in project 2 illustrate interdisciplinarity and are shown in Figures 4 (theoretical interdisciplinarity) and Figure 5 (methodological interdisciplinarity).

[Figure 4 near here]

[Figure 5 near here]

Finally, in project 3 we find similarities with project 2 in the articulation of interdisciplinary content and topics. This is exemplified by the research question "What factors are involved in the characteristics of the soil type and how do they influence the diversity of vegetation present on the north slope of the RNRC?". In project 3, a key feature is how teachers use methodological interdisciplinarity. In their methodology the teachers established different study areas, taking samples and borrowing procedures from biology, especially plant ecology, to compare the diversity of species in different zones, and from physics to investigate how the mass and volumetric flow rate of water 
in the river was affecting the number of species around it. The teachers also used some methods from chemistry to evaluate the soil compositions, similarly to project 2.

Two study areas were established. One was an 'upper zone', an area located 200 $\mathrm{m}$ from the riverbank. The other was a 'lower zone', an area located on the slope of the river. In each area, a quadrat ( $5 \times 5 \mathrm{~m})$ was established, where samples were gathered, observations made and photographs taken (see Figure 6).

[Figure 6 near here]

\section{Teaching and learning of science through RPPs in outdoor science activities}

The aim of this section is to answer the second research question of this study: Can a RPP be a pedagogical resource to generate positive changes in professional development within the practice of managing outdoor science activities?

Regarding the perceptions about teaching and learning outside the classroom, teachers suggested that these types of activities are essential for science education. Teachers mentioned that the importance of working in this way is based on developing a broader understanding of complex issues and real-life problems, saving time and simplifying their work in the classroom. Furthermore, they found differences between working inside the classroom than outside the classroom:

The differences are related to saving time and simplifying our work. Normally, you tend to fall into unnecessary repetitions of the subjects, and as a teacher of the subjects of biology and chemistry at the same time, I visualize that students lose interest when one teaches something they already know or repeats. (Biochemistry teacher)

In addition, teachers suggested that a pedagogical fieldtrip would help consolidate the content covered in classes, also benefiting the development of learning, the appropriation of concepts, thinking, reasoning and research skills from a real-life problem:

I think that addressing a problem in real life, was key to consolidating the contents worked, to 'download' and apply them and to be able to relate the different specialties, I think it would not have been possible to have seen it only in the class sessions (...) I feel that benefited learning, thinking reasoning and research skills. (Biology teacher)

Teachers working through RPPs were able to connect different topics seen during their Master's modules with their visit to the Río Clarillo National Reserve through the ITLS approach. The aim was to develop a project making use of previous information about the Río Clarillo National Reserve, connecting different subjects and science phenomena. The activity about the national nature reserve had an interdisciplinary potential for a variety of learning benefits. According to the perceptions of teachers about ITLS and science outdoors, activities developed through the ITLS approach facilitated teachers' thinking about natural phenomena by familiarising them with realworld problems, which are not easily comprehensible or resolvable from a single disciplinary framework, as highlighted by one science teacher:

Contributions of interdisciplinary teaching through science outdoors activities for the teaching-learning process are evident (...) it allows us to solve issues that through distinct subjects would not have been possible, such as the case of 
environmental issues (...) I think they allow us to develop critical thinking, scientific reasoning, drawing conclusions from different perspectives and encouraging meaningful learning. (Biochemistry teacher)

Perceptions about RPP and collaborative work are clear. Teachers consider a key aspect of the outdoor science activity to be the work developed through collaborative partnerships. They considered that a RPP approach appears as a pedagogical resource to generate positive changes in professional development within the practice of managing outdoor science, considering that: a) an experience carried out with a RPP approach offers scaffolding and support between learners who share different experiences and expertise, not only among teachers but also with researchers; b) the experience is a contribution to their teaching practice and the planning of future school activities. As one teacher put it:

The topics were born from conversations with my colleagues, where we could share experiences about some activities that we have wanted to be developed in our subjects and with our students but had never been translated. That is why I think that this pedagogical outdoor activity is a great contribution to our teaching practice and future activities that can be developed outside of our schools (...) The researchers were very helpful, because important questions about the methodology were solved. (Physics teacher)

However, some obstacles are related to the time required and for the need to make a previous visit to the National Reserve. The majority of the teachers complained about the time needed for the implementation, and there were also complaints about the guidelines given by researchers at each stage. On the other hand, one teacher wanted more time to have been spent on the implementation:

I think it would have been favourable, to have made more than one visit to the place, in the first instance to identify the problem and then to be able to measure the variables, since we could have carried more appropriate instruments. (Biology teacher)

Another obstacle is related to the preconceptions among teachers about their own disciplines and regarding their training in interdisciplinarity activities.:

The obstacles focused mainly on the ideas that teachers have about our discipline, because we think that through it, we can solve an infinite number of issues. As a group we had to talk, expose our points of view and take common agreements to understand that all disciplines have their relevance and that they could contribute in some way to the study that was carried out. (Biology teacher)

In addition, the cultural boundaries between researchers and practitioners must be considered (Penuel et al., 2015). In this case, another obstacle was related to the guidelines provided by the researchers during the process and to limitations between the roles of the teachers and of the researchers. Some of the teachers felt it wasn't really a partnership between themselves and the researchers as they felt that the researchers simply wanted the teachers to come up with the ideas:

I feel that the professors / researchers were willing to contribute in our work, however we as students proposed what and how to do it, I think that, if we had 
been very disoriented, they would have helped us more, but it was not the case. (Biology teacher).

However, and conversely, teachers felt supported during the development and production of the scientific posters:

Especially in the preparation of the scientific poster, they helped us to limit the problem, find information about the variables, relate everything and translate it in an understandable and summarised way, that was the challenge. (Chemistry teacher)

Overall, the findings from teachers' perceptions reveal benefits of RPP and ITLS, as tools for the management of outdoor activities, supporting the importance, relevance and feasibility of learning science outside the classroom.

\section{Discussion and conclusions}

As a result of outdoor science activities using an interdisciplinary approach, teachers may find their disciplinary knowledge and skills improved, with the result that they are more able to answer research questions in real environments. Moreover, through theoretical and methodological interdisciplinarity, teachers may foster the creation of new conceptual categories and methodological tools, using concepts or procedures from other disciplines in an auxiliary relationship (Klein, 2017). From this perspective, interdisciplinary outdoor science activities have the potential to organise scientific topics and ideas and answer questions across different disciplines (DeZure, 2017). Furthermore, these kinds of activities provide an opportunity to develop problemsolving abilities, generally considered as an instance of higher order thinking within science courses. For instance, in the activity teachers were able to identify and analyse a problem, develop a plan, implement it and then undertake an evaluation to answer the original research question. Thus, interdisciplinary teaching outside the classroom can lead learners to have more meaningful learning experiences and develop these skills.

Interdisciplinary outdoor science activities carried out through RPPs appear to generate common work objectives, addressing conceptual, procedural and attitudinal aspects across science subjects. Therefore, collaboration with researchers can play a key role in facilitating interdisciplinary teaching.

This research revealed some benefits of RPPs and ITLS as pedagogical approaches to supporting learning outside the classroom. There are other studies of RPPs and their role in the production of knowledge that show that this type of mutual support and learning networks can contribute to the construction of a more robust educational theory and practice and also function as a tool for professional development (McLaughlin \& Black-Hawkins, 2007; Wang \& Zhang, 2014). In the research presented in this article, the experience provided a rationale for more collaborative-action work projects to foster curricular planning of outdoor science activities and in-service teacher education. RPPs benefit from collaborative learning in all the phases of an outdoor science activity. However, the cultural, professional, and disciplinary boundaries between practitioners and researchers must be considered (Penuel et al., 2015).

Collaboration between researchers and in-service teachers allows the science education community to respond to some of the dissuasive elements faced by teachers when considering research work, such as limited time availability and the professional culture that clearly distinguishes the disciplinary field of a practising teacher from that of a researcher (Chow, Chu, Tavares, \& Lee, 2015). The results of this study are 
consistent with research conducted by Yuan and Lee (2015), where these kinds of partnerships were found to play a role in changing teachers' beliefs and perceptions about research. For example, academic research is often a seen as a 'mysterious' field among teachers. Thus, RPPs and ITLS can provide an opportunity to facilitate the translation of research into practice.

It is not trivial then to refer to the place that has traditionally been granted to research as an exclusive practice of the academy (Yuan \& Lee, 2015), housed only in academic spaces and, therefore, apart from teachers. One of the benefits of RPPs is that it allows a recognition that knowledge about effective teaching processes is not the exclusive property of universities and researchers, but also belongs to teachers themselves. This new role of what we might term a 'research teacher' is effectively the same as that terms 'teacher scientist' by (Guerrero et al., 2019) and is considered a critical factor in the effective linking of teaching practice to the process of research and reflection.

For some, empowerment of the investigative teaching role, and the response to this historical role, must also come from the restructuring of teacher training with a goal to encourage inquiry as part of the nature of teaching and schooling (Gray \& CampbellEvans, 2002). This can happen along with the university-school partnerships that strengthen research capacities and that could result in the reconfirmation of educational research inherited from a more conventional model in which researchers 'transmit' their knowledge to schools science teachers.

Although it would become a key requirement within RPPs that teachers develop skills and knowledge in research as part of their professional development, there are some difficulties to position and articulate research with the daily practice of teachers in terms of implications and the relationships between teaching practice, formative research and self-reflection activities for the transformation of practice. It is from these processes that teachers can appreciate the learning of their students in perspective, offering insights on school and classroom practice and opportunities for localized actions (Gray \& Campbell-Evans, 2002).

\section{Implications and future research}

With collaborative work, science teachers are expected to share experiences with other teachers in their establishment and develop a methodological and research proposal across different disciplines that helps to share pedagogical spaces and break the excessive fragmentation of content in science education. Along with this, teachers are also required to develop reflection processes allowing them to interact, share experiences, clarify doubts, share strengths and resolve weaknesses based on collaboration, research and a holistic view of their work (Chow et al., 2015). In addition, RPPs and ITLS have been shown to be potential resources and tools for professional development, in which teachers address their weaknesses in outdoor science activities, sharing techniques, strategies and experiences that contribute to the value of teamwork.

Finally, it is expected that this research will contribute to the valuable work of teaching and learning within outdoors activities - from an interdisciplinary focus placing students as the centre of learning and the integration of knowledge. The methods and content of different subjects can influence the relationship and construction of facts and phenomena of nature, society and thought (Tobi \& Kampen, 2017).

This would confirm the need to intervene, restructure or form initiatives in the planning of science curricula and programmes, highlighting the value of theoretical and 
methodological interdisciplinarity to connect different disciplines and topics from a real-world perspective. This in turn can aid the reform of the relationships and transformations that occur in students' minds when interacting with the points of view obtained from different subjects about a real phenomenon (e.g., Rushton \& Reiss, 2019)).

All in all, the value of the research presented here is in considering the experiences of teachers and the work they undertake before and after field trips. Such work seeks to enhance the teaching-research role, which should help ensures that the response to the diagnosed problem is based on empirical evidence and results in effective ways of improving teacher and student understanding and practice.

\section{Acknowledgements}

The authors would like to thank the in-service teachers and researchers who participated in the Research Practice Partnerships and generously shared their perceptions and experiences for this study. We are also grateful to two anonymous reviewers for invaluable feedback.

\section{Disclosure statement}

No potential conflict of interest was reported by the authors.

\section{Funding}

This research did not receive any specific grant from funding agencies in the public, commercial or not-for-project sectors.

\section{ORCID}

Gonzalo R. Guerrero-Hernández https://orcid.org/0000-0002-7207-4880

Michael J. Reiss http://orcid.org/0000-0003-1207-4229

\section{References}

Apostel, L., Berger, G., Briggs, A., \& Michaud, G. (1972). L'interdisciplinarité : problémes d'enseignement et de recherche dans les universités. Paris: Organisation de coopèration et de développement Èconomiques.

Ayotte-Beaudet, J. P., Potvin, P., Lapierre, H. G., \& Glackin, M. (2017). Teaching and Learning Science Outdoors in Schools' Immediate Surroundings at K-12 Levels: A Meta-Synthesis. EURASIA Journal of Mathematics, Science and Technology Education, 13(8), 5343-5363. doi:10.12973/eurasia.2017.00833a

Behrendt, M., \& Franklin, T. (2014). A Review of Research on School Field Trips and Their Value in Education. International Journal of Environmental \& Science Education, 3(3), 235-245. doi:10.12973/ijese.2014.213a

Bencze, L., \& Hodson, D. (1999). Changing practice by changing practice: Toward more authentic science and science curriculum development. Journal of Research in Science Teaching, 36(5), 521-539. doi:10.1002/(sici)1098-2736(199905)36:5<521::Aid-tea2>3.0.Co;2-6

Braund, M., \& Reiss, M. (2006). Towards a More Authentic Science Curriculum: The contribution of out-of-school learning. International Journal of Science Education, 28(12), 1373-1388. doi:10.1080/09500690500498419

Boix Mansilla, V. (2017). Interdisciplinary Learning: A Cognitive-Epistemological Foundation In R. Frodeman (Ed.), The Oxford Handbook of Interdisciplinarity (2 ed.) (pp. 261-275). New York: Oxford University Press.

Boix Mansilla, V., \& Duraisingh, E. (2007). Targeted Assessment of Students' Interdisciplinary Work: An Empirically Grounded Framework Proposed. 78(2), 215-237. doi:10.1353/jhe.2007.0008

Boix Mansilla, V., Gardner, H., \& Miller, W. (2000). On disciplinary lenses and interdisciplinary work. In S. S. Wineburg \& P. Grossman (Eds.), Interdisciplinary curriculum: challenges to implementation (pp. 17-38). New York: Teachers College Press. 
Bruun, H., Hukkinen, J., Huutoniemi, K., \& Klein, J. T. (2005). Promoting interdisciplinary research: The case of the Academy of Finland. (Vol. 2005). Helsinki: Publications of the Academy of Finland. Academy of Finland.

Chow, K., Chu, S. K. W., Tavares, N., \& Lee, C. W. Y. (2015). Teachers as researchers: A discovery of their emerging role and impact through a school-university collaborative research. Brock Education Journal, 24(2), 20-39. doi:10.26522/brocked.v24i2.374

CIAE. (2018). Evolución de la oferta de formación docente en carreras de Pedagogía en Educación MediaINFORME OFD N5, CIAE.

Delgado, E., \& Alario, M. T. (1994). La interacción fuera del aula: Itinerarios, salidas y paseos. Tabanque: Revista pedagógica, 9, 155-178.

DeZure, D. (2017). Interdisciplinary Pedagogies in Higher Education. In F. Frodeman (Ed.), The Oxford Handbook of Interdisciplinarity (2 ed.) (pp. 558-572). New York: Oxford University Press.

Dillon, J., Morris, M., O’Donnell, L., Reid, A., Rickinson, M., \& Scott, W. (2005). Engaging andlearning with the outdoors - the final report of the outdoor classroom in a rural context action research project. Slough: National Foundation for Education Research.

Falk, J. H., \& Dierking, L. D. (1997). School Field Trips: Assessing Their Long-Term Impact. Curator: The Museum Journal, 40(3), 211-218. doi:10.1111/j.2151-6952.1997.tb01304.x

Falk, J. H., \& Dierking, L. D. (2000). Learning from museums: visitor experiences and the making of meaning (Vol. American Association for State and Local History book series). Walnut Creek, CA: AltaMira Press.

Falk, J. H., Martin, W. W., \& Balling, J. D. (1978). The novel field-trip phenomenon: Adjustment to novel settings interferes with task learning. Journal of Research in Science Teaching, 15(2), 127134. doi:10.1002/tea.3660150207

Frodeman, R. (2014). Sustainable knowledge: A theory of interdisciplinarity. London: Palgrave Pivot.

Gehlert, S., Murray, A., Sohmer, D., McClintock, M., Conzen, S., \& Olopade, O. (2010). The Importance of Transdisciplinary Collaborations for Understanding and Resolving Health Disparities. Social Work in Public Health, 25(3-4), 408-422. doi:10.1080/19371910903241124

Glackin, M. A. (2019). 'It's more than a prop': Professional development session strategies as sources of teachers' self-efficacy and motivation to teach outside the classroom. Professional Development in Education, 45(3), 372-389. doi:10.1080/19415257.2018.1490917

Glackin, M. A., \& King, H. (2018). Understanding Environmental Education in Secondary Schools in England: Prespectives from Policy (Report 1). London: King's College London.

Glackin, M. A., King, H., Cook, R., \& Greer, K. (2018). Understanding Environmental Education in Secondary schools in England: The Practitioners' Perspective (Report 2). London: King's College London.

Gray, J., \& Campbell-Evans, G. (2002). Beginning Teachers as Teacher-Researchers. 27(1). doi:10.14221/ajte.2002v27n1.4

Guerrero, G., Joglar, C., \& Carrasco, V. (2019). Salidas pedagógicas interdisciplinares: rutas didácticas hacia el aprendizaje en el marco de una investigación asociativa Universidad-Escuela. In G. Guerrero, R. Fernández, \& G. Watson (Eds.), Investigando Juntos: Experiencias Asociativas entre Escuelas y la Universidad de Santiago de Chile (pp. 70-92). Santiago: Editorial Usach.

Hickey, G., \& Kipping, C. (1996). A multi-stage approach to the coding of data from open-ended questions. Nurse Researcher, 4(1), 81-91.

Hsieh, H.-F., \& Shannon, S. E. (2005). Three Approaches to Qualitative Content Analysis. Qualitative Health Research, 15(9), 1277-1288. doi:10.1177/1049732305276687

Hudak, P. E. (2003). Campus Field Exercises for Introductory Geoscience Courses. Journal of Geography, 102(5), 220-225. doi:10.1080/00221340308978550

King, H., \& Glackin, M. (2010). Supporting science learning in out-of-school contexts. In J. Osborne \& J. Dillon (Eds.), Good Practice in Science Teaching (pp. 259-273). London: Open University Press

Klein, J. T. (2005). Integrative Learning and Interdisciplinary Studies. Peer Review, 7 (4), 8-10.

Klein, J. T. (2017). Typologies of Interdisciplinarity: The Boundary Work of Definition. In F. Frodeman (Ed.), The Oxford Handbook of Interdisciplinarity (2 ed.) (pp. 21-34). New York: Oxford University Press.

Knight, D. B., Lattuca, L. R., Kimball, E. W., \& Reason, R. D. (2013). Understanding Interdisciplinarity: Curricular and Organizational Features of Undergraduate Interdisciplinary Programs. Innovative Higher Education, 38(2), 143-158. doi:10.1007/s10755-012-9232-1

Krepel, W. J., \& Duvall, C. R. (1981). Field trips : a guide for planning and conducting educational experiences. Washington, D.C.: National Education Association.

Lattuca, L. (2001). Creating Interdisciplinarity: Interdisciplinary Research and Teaching among College and University Faculty. . Nashville Vanderbilt University Press.

Guerrero, G. \& Reiss, M. J. (2020) Science outside the classroom: Exploring opportunities from interdisciplinarity and research-practice partnerships. International Journal of Science Education. 
Madden, M. E., Baxter, M., Beauchamp, H., Bouchard, K., Habermas, D., Huff, M., .. . Plague, G. (2013). Rethinking STEM Education: An Interdisciplinary STEAM Curriculum. Procedia Computer Science, 20, 541-546. doi:10.1016/j.procs.2013.09.316

McLaughlin, C., \& Black-Hawkins, K. (2007). School-university partnerships for educational researchdistinctions, dilemmas and challenges. 18(3), 327-341. doi:10.1080/09585170701589967

Michie, M. (1998). Factors influencing secondary science teachers to organise and conduct field trips. Australian Science Teachers Journal, 44(4), 43-50. Retrieved from http://search.proquest.com.ezproxy.lib.monash.edu.au/docview/194498429/13E584736A15CA0 $39 \mathrm{FF} / 11$ ?accountid=12528

Miller, R. (1982). Varieties of interdisciplinary approavhes in the social sciences. Issues in Integrative Studies, 1, 1-37.

Mohamed, M., Perez, M., \& Montero, M. (2017). Salidas pedagógicas como metodología de refuerzo en la Enseñanza Secundaria. ReiDoCrea, 6, 194-210.

Murga-Menoyo, M. Á., \& Novo, M. (2017). Sostenibilidad, desarrollo «glocal» y ciudadanía planetaria. Referentes de una Pedagogía para el desarrollo sostenible. Teoría de la Educación. Revista Interuniversitaria, 29(1), 55. doi:10.14201/teoredu2915578

Nabors, M. L., Edwards, L. C., \& Murray, R. K. (2009). Making the case for field trips:What research tells us and what site coordinators have to say. Education, 129(4), 661-667.

NGSS, L. S. (2013). Next Generation Science Standards: For States, By States. Washington, DC: Achieve, Inc.

OECD. (2018). The future of education and skills, Education 2030. Paris: OECD Publishing.

Penuel, W. R., Allen, A.-R., Coburn, C. E., \& Farrell, C. (2015). Conceptualizing Research-Practice Partnerships as Joint Work at Boundaries. Journal of Education for Students Placed at Risk (JESPAR), 20(1-2), 182-197. doi:10.1080/10824669.2014.988334

Perales, F. J., \& Guerrero, G. (2017). Inter y transdisciplinariedad en textos escolares de física: un estudio de dos casos. Ápice. Revista de Educación Científica., 1(1), 74-89. doi:10.17979/arec.2017.1.1.1992

Power, S., Taylor, C., Rees, G., \& Jones, K. (2009). Out-of-school learning: Variations in provision and participation in secondary schools. Research Papers in Education, 24, 439-460. doi:10.1080/02671520802584095

Rennie, L. (2014). Learning Science Outside of School. In N. Lederman \& S. Abell (Eds.), Handbook of Research on Science Education (pp. 120-144): Routledge.

Rickinson, M., Dillon, J., Teamey, K., Morris, M., Choi, M. Y., Sanders, D., \& Benefield, P. (2004). A Review of Research on Outdoor Learning. Shrewsbury: Field Studies Council.

Rushton, E. A. C., \& Reiss, M. J. (2019). From science teacher to 'teacher scientist': exploring the experiences of research-active science teachers in the UK. International Journal of Science Education, 41(11), 1541-1561. doi:10.1080/09500693.2019.1615656

Scarce, R. (1997). Field Trips as Short-Term Experiential Education. Teaching Sociology, 25(3), 219 226. doi: $10.2307 / 1319398$

Spelt, E. J. H., Biemans, H. J. A., Tobi, H., Luning, P. A., \& Mulder, M. (2009). Teaching and Learning in Interdisciplinary Higher Education: A Systematic Review. Educational Psychology Review, 21(4), 365-378. doi:10.1007/s10648-009-9113-z

Tal, T., \& Morag, O. (2009). Reflective Practice as a Means for Preparing to Teach Outdoors in an Ecological Garden. Journal of Science Teacher Education, 20(3), 245-262. doi:10.1007/s10972009-9131-1

Tobi, H., \& Kampen, J. K. (2017). Research design: the methodology for interdisciplinary research framework. Quality \& Quantity, 1209-1225. doi:10.1007/s11135-017-0513-8

Wang, Q., \& Zhang, H. (2014). Promoting teacher autonomy through university-school collaborative action research. 18(2), 222-241. doi:10.1177/1362168813505942

You, H. S. (2017). Why Teach Science with an Interdisciplinary Approach: History, Trends, and Conceptual Frameworks. Journal of Education and Learning, 6(4), 66-77. doi:10.5539/jel.v6n4p66

Yuan, R., \& Lee, I. (2015). Action research facilitated by university-school collaboration. 69(1), 1-10. doi:10.1093/elt/ccu031 


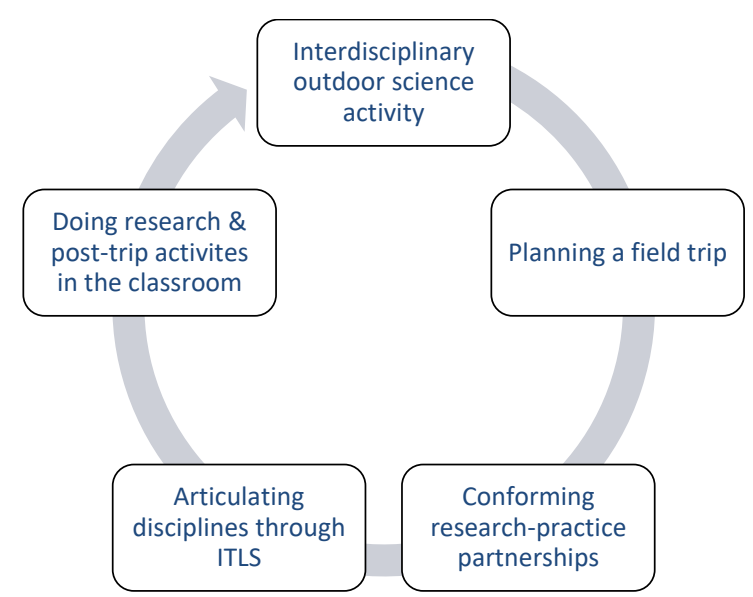

Figure 1. Phases of the interdisciplinary science outdoor activity through a RPP. 


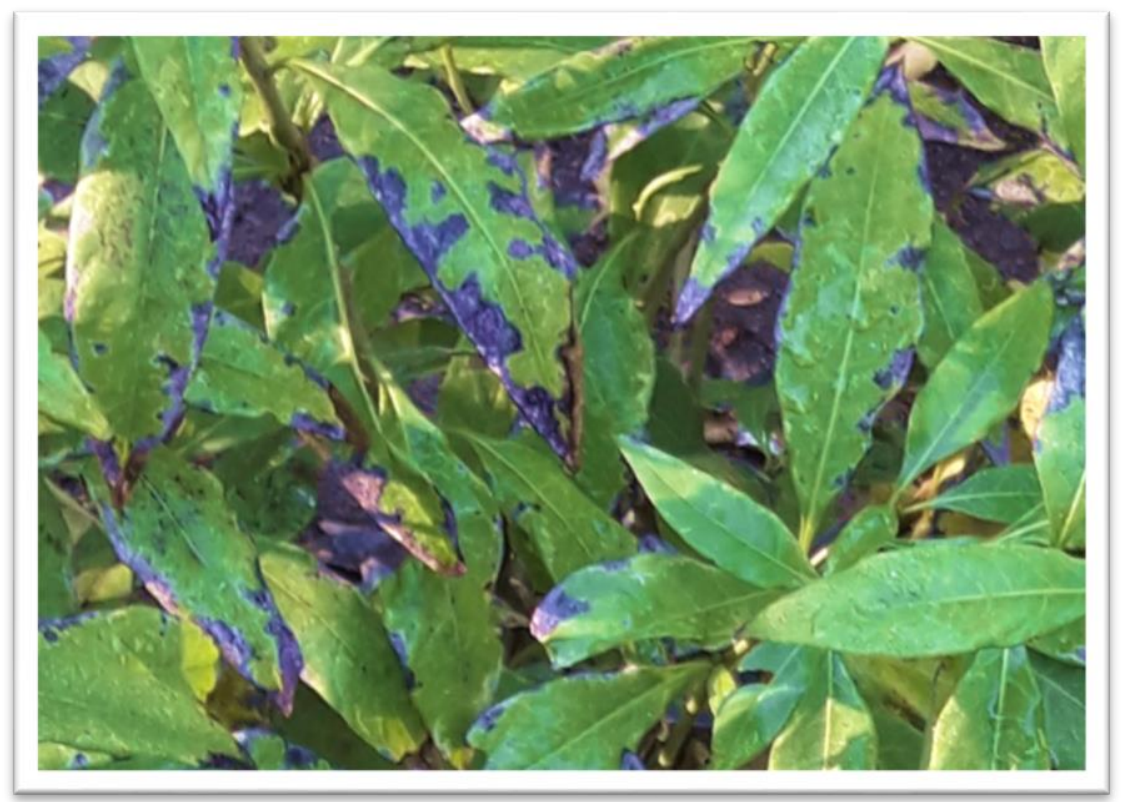

Figure 2. Cestrum parqui leaves damaged by effects of low temperature and high humidity (project 1). 


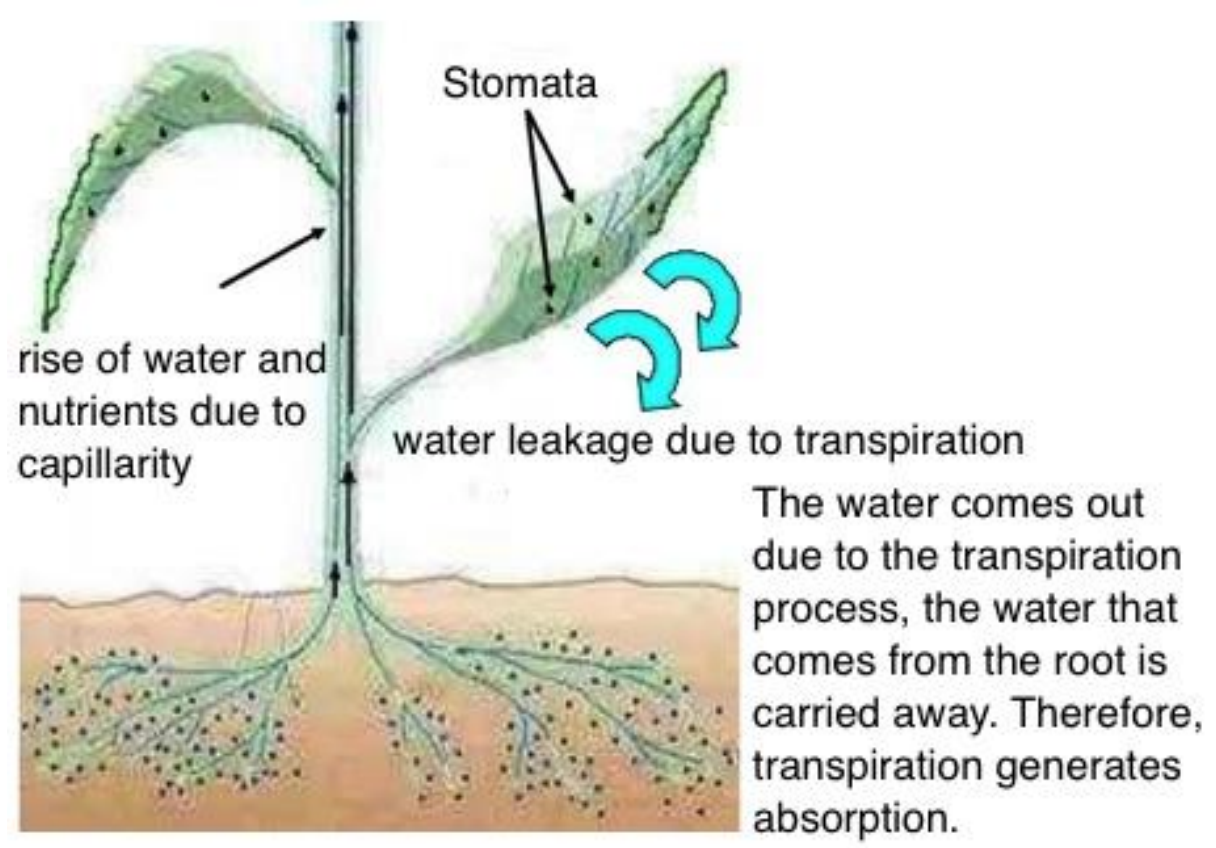

Figure 3. Part of the poster produced by the teachers undertaking project 1 . Effects of transpiration on water absorption in plants. (Source: Diagram from scientific poster made by in-service teachers in project 1.) 


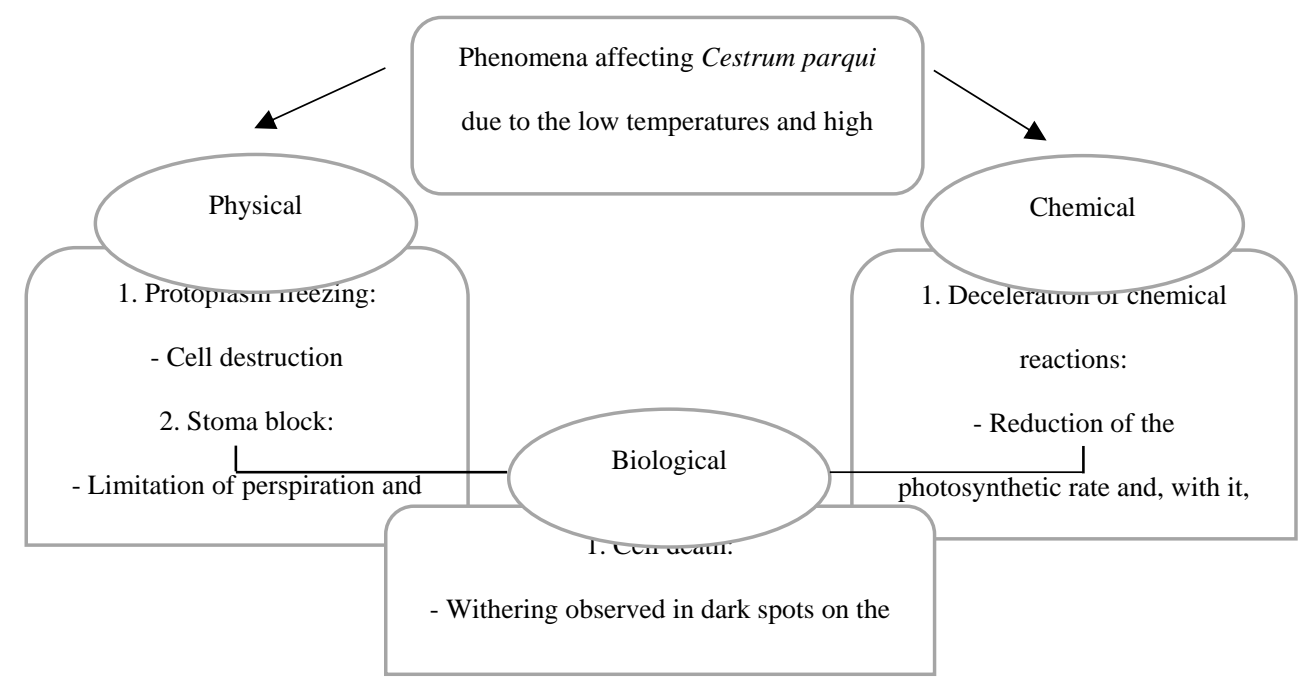

Figure 4. Example of theoretical interdisciplinarity: Effects of low temperatures and high humidity on Cestrum parqui in the Río Clarillo National Reserve. (Source: Diagram from scientific poster made by in-service teachers in project 1.) 
Methods

Comparative study based on the "Manual of basic methods of sampling and analysis in Ecology". It was performed in the following stages:

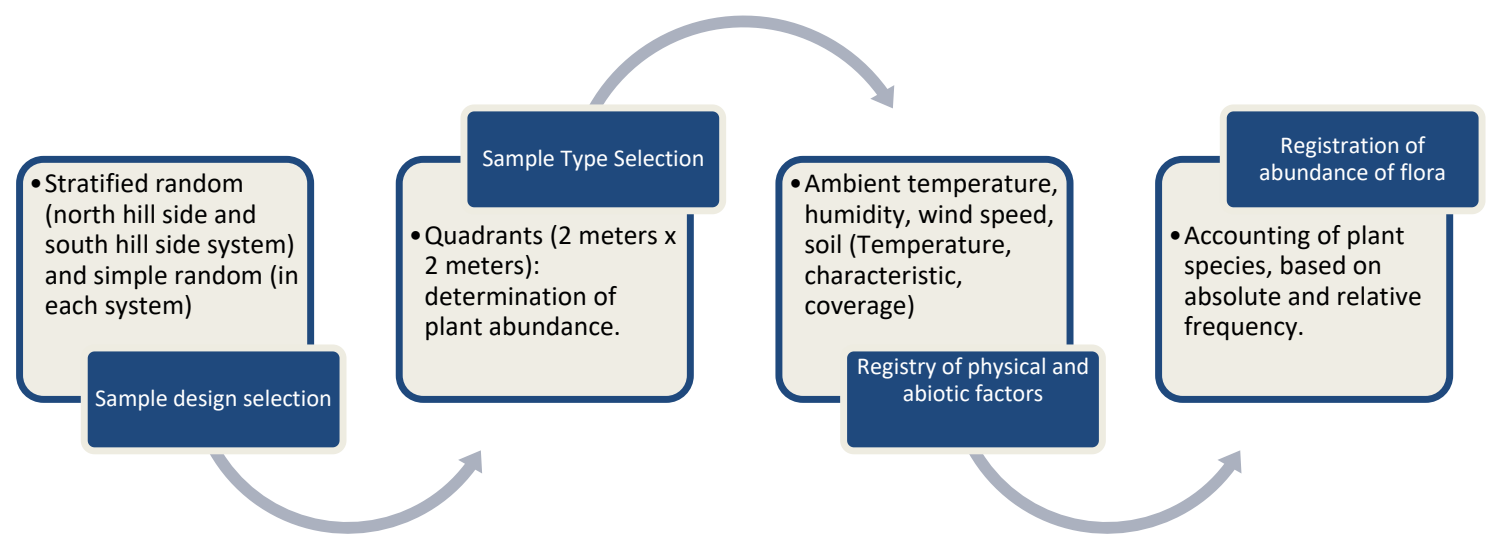

Figure 5. Example of methodological interdisciplinarity: Diagram using methods from different disciplines in project 2. (Source: Diagram from scientific poster made by in-service teachers in project 2.) 


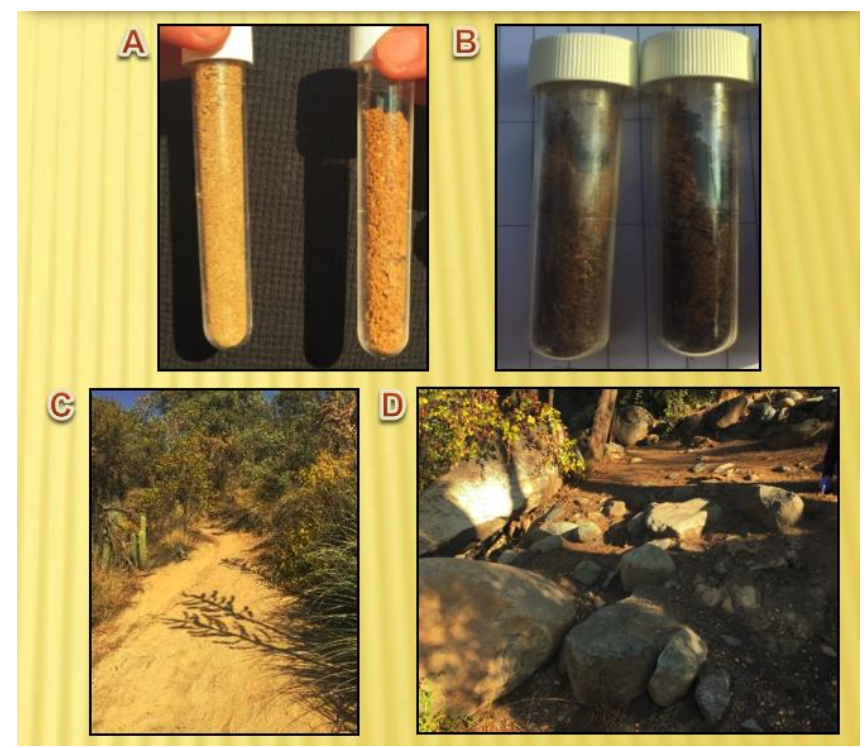

Figure 6. Images of the type of soil in the study areas. A) Chemical composition of the soil in the upper zone. B) Chemical composition of the soil in the lower zone. C) Diversity of vegetation in the upper zone. D) Diversity of vegetation in the lower zone. (Source: from scientific poster made by in-service teachers in project 3.) 
Table 1. Outdoor science projects undertaken and the teacher and researcher profiles

\begin{tabular}{|c|c|c|c|}
\hline & Project 1 & Project 2 & Project 3 \\
\hline $\begin{array}{l}\text { General } \\
\text { objective }\end{array}$ & $\begin{array}{l}\text { Analyse the } \\
\text { effects of } \\
\text { temperature } \\
\text { and humidity } \\
\text { on Cestrum } \\
\text { parqui } \\
\text { flowering } \\
\text { within the } \\
\text { reserve }\end{array}$ & $\begin{array}{l}\text { Examine how solar } \\
\text { exposure and other } \\
\text { abiotic factors affect } \\
\text { the presence of flora } \\
\text { on the hillsides of the } \\
\text { reserve }\end{array}$ & $\begin{array}{l}\text { Analyse } \\
\text { different } \\
\text { factors } \\
\text { affecting soils } \\
\text { and their } \\
\text { relation to } \\
\text { vegetation and } \\
\text { diversity } \\
\text { within the } \\
\text { north hillside } \\
\text { of the reserve }\end{array}$ \\
\hline $\begin{array}{l}\text { Disciplines and } \\
\text { interdisciplinary } \\
\text { areas of work }\end{array}$ & $\begin{array}{l}\text { Physics, } \\
\text { biochemistry, } \\
\text { chemistry and } \\
\text { biology } \\
\text { (ecology, } \\
\text { botany and } \\
\text { plant } \\
\text { physiology) }\end{array}$ & $\begin{array}{l}\text { Physics, mathematics, } \\
\text { biology (ecology), } \\
\text { chemistry, geology, } \\
\text { agrophysics, } \\
\text { agrochemistry and } \\
\text { geography. }\end{array}$ & $\begin{array}{l}\text { Physics, } \\
\text { biology (plant } \\
\text { ecology) and } \\
\text { chemistry }\end{array}$ \\
\hline $\begin{array}{l}\text { Specific } \\
\text { interdisciplinary } \\
\text { topics and } \\
\text { content }\end{array}$ & $\begin{array}{l}\text { Temperature, } \\
\text { transpiration, } \\
\text { relative } \\
\text { humidity, } \\
\text { capillarity, } \\
\text { chlorosis. }\end{array}$ & $\begin{array}{l}\text { Photosynthetic rate, } \\
\text { biotic and abiotic } \\
\text { factors, native flora of } \\
\text { Chile, solar exposure } \\
\text { and radiation }\end{array}$ & $\begin{array}{l}\text { Heath and } \\
\text { temperature, } \\
\text { soils, } \\
\text { superficial } \\
\text { humidity of } \\
\text { soils, types of } \\
\text { plants, roots } \\
\text { and rocks and } \\
\text { mass and } \\
\text { volumetric } \\
\text { flow rate of } \\
\text { water. }\end{array}$ \\
\hline $\begin{array}{l}\text { In-service } \\
\text { teachers' profile } \\
\text { in the RPP }\end{array}$ & $\begin{array}{l}\text { Physics and } \\
\text { natural } \\
\text { sciences } \\
\text { teacher, } \\
\text { Biology and } \\
\text { natural } \\
\text { sciences } \\
\text { teacher, } \\
\text { Chemistry } \\
\text { teacher }\end{array}$ & $\begin{array}{l}\text { Physics and } \\
\text { mathematics } \\
\text { teacher, } \\
\text { Biology and } \\
\text { chemistry } \\
\text { teacher, } \\
\text { Biology and } \\
\text { natural } \\
\text { sciences } \\
\text { teacher }\end{array}$ & $\begin{array}{l}\text { Physics } \\
\text { teacher, } \\
\text { Biochemistry } \\
\text { teacher, } \\
\text { Chemistry } \\
\text { teacher }\end{array}$ \\
\hline $\begin{array}{l}\text { Researchers' } \\
\text { profile in the } \\
\text { RPP }\end{array}$ & \multicolumn{3}{|c|}{$\begin{array}{l}\text { Biology educator, Chemistry educator and Physics and } \\
\text { mathematics educator }\end{array}$} \\
\hline
\end{tabular}


Appendix 1. Teacher profiles and contextual information about schools

\begin{tabular}{|c|c|c|c|c|}
\hline Teacher & $\begin{array}{l}\text { Undergraduate course } \\
\text { and career }\end{array}$ & Subject(s) taught and level(s) & $\begin{array}{l}\text { Length of teaching } \\
\text { experience }\end{array}$ & $\begin{array}{l}\text { Type of } \\
\text { school }\end{array}$ \\
\hline Teacher 1 & Biochemistry & $\begin{array}{l}\text { Biochemistry. Secondary and } \\
\text { higher education levels. }\end{array}$ & $\begin{array}{l}0 \text { years (only experience is } \\
\text { tutoring at secondary level } \\
\text { and as a researcher assistant) }\end{array}$ & $\begin{array}{l}\text { Higher } \\
\text { Education and } \\
\text { tutoring }\end{array}$ \\
\hline Teacher 2 & $\begin{array}{l}\text { Natural Sciences; } \\
\text { Physics teacher }\end{array}$ & $\begin{array}{l}\text { Physics and Natural Sciences. } \\
\text { Secondary level. }\end{array}$ & 4 years & Private \\
\hline Teacher 3 & $\begin{array}{l}\text { Biology; Natural } \\
\text { Sciences teacher }\end{array}$ & $\begin{array}{l}\text { Biology and Natural Sciences. } \\
\text { Secondary level and higher } \\
\text { education levels. }\end{array}$ & 21 years & Subsidised \\
\hline Teacher 4 & $\begin{array}{l}\text { Biology; Chemistry } \\
\text { teacher }\end{array}$ & $\begin{array}{l}\text { Biology and Chemistry. } \\
\text { Secondary level. }\end{array}$ & 6 years & Public \\
\hline Teacher 5 & $\begin{array}{l}\text { Mathematics; Physics } \\
\text { teacher }\end{array}$ & $\begin{array}{l}\text { Physics and mathematics. } \\
\text { Secondary level. }\end{array}$ & 2 years & Subsidised \\
\hline Teacher 6 & $\begin{array}{l}\text { Physics; Physics } \\
\text { teacher }\end{array}$ & Physics. Secondary level. & 5 years & Private \\
\hline Teacher 7 & $\begin{array}{l}\text { Biology; Biology } \\
\text { teacher }\end{array}$ & $\begin{array}{l}\text { Biology and Natural Sciences. } \\
\text { Secondary level and higher } \\
\text { education level. }\end{array}$ & 5 years & Public \\
\hline Teacher 8 & $\begin{array}{l}\text { Elementary teacher; } \\
\text { Mathematics Teacher }\end{array}$ & Mathematics. Primary level. & 0 years & - \\
\hline Teacher 9 & $\begin{array}{l}\text { Bachelor's degree in } \\
\text { nutrition; Chemistry }\end{array}$ & $\begin{array}{l}\text { Chemistry. Higher education } \\
\text { level. }\end{array}$ & 4 years of experience & $\begin{array}{l}\text { Higher } \\
\text { Education - } \\
\text { Undergraduate } \\
\text { level }\end{array}$ \\
\hline
\end{tabular}


Appendix 2: Questionnaire about teachers' perceptions of Interdisciplinary Teaching and Learning of Science through outdoors science activities set in a Research-Practice Partnership.

1. What is your opinion about approaching science field trips from an interdisciplinary perspective? 2. What is your opinion about addressing a real-world problem through an interdisciplinary outdoor learning activity or field trip? In your opinion, what would the differences have been if the target contents had been tackled only during formal lessons inside the classroom?

3. What are your perceptions towards the benefits of conducting an interdisciplinary field trip in terms of the students' learning, thinking skills and research abilities?

4. Do you feel that there was enough freedom to find a research topic and address a problem within your group and project?

5. What are your perceptions of your teachers' support when it came to choose your methodological approach and defining your research problem?

6. In your opinion, did the experience of carrying out an interdisciplinary field trip contribute to your professional development as a teacher and a researcher?

7. What is your general opinion on the activity? Mention some weaknesses, strengths, facilitators and something to improve the activity. 